\title{
Corrigendum: Exploring the Secretomes of Microbes and Microbial Communities Using Filamentous Phage Display
}

\section{OPEN ACCESS}

Edited by:

Gilbert Greub,

University of Lausanne, Switzerland

Reviewed by:

Tatsuo Shioda,

Osaka University, Japan

Claire Bertelli,

Simon Fraser University, Canada

*Correspondence:

Dragana Gagic

d.gagic@massey.ac.nz

Specialty section:

This article was submitted to

Virology,

a section of the journal

Frontiers in Microbiology

Received: 18 April 2016

Accepted: 31 May 2016

Published: 14 June 2016

Citation:

Gagic D, Ciric M, Wen WX, Ng F and

Rakonjac J (2016) Corrigendum:

Exploring the Secretomes of Microbes

and Microbial Communities Using

Filamentous Phage Display.

Front. Microbiol. 7:927.

doi: 10.3389/fmicb.2016.00927

\section{Dragana Gagic ${ }^{1,2 *}$, Milica Ciric ${ }^{1,2}$, Wesley X. Wen ${ }^{1}$, Filomena $\mathrm{Ng}^{1,2}$ and Jasna Rakonjac ${ }^{1}$ \\ ${ }^{1}$ Institute of Fundamental Sciences, Massey University, Palmerston North, New Zealand, ${ }^{2}$ Animal Science, Grasslands \\ Research Centre, AgResearch Ltd., Palmerston North, New Zealand}

Keywords: phage display, secretome, adhesins, metagenomics, next generation sequencing, bacteriophage

\section{A corrigendum on}

Exploring the Secretomes of Microbes and Microbial Communities Using Filamentous Phage Display

by Gagic, D., Ciric, M., Wen, W. X., Ng, F., and Rakonjac, J. (2016). Front. Microbiol. 7:429. doi: 10.3389/fmicb.2016.00429

Reason for Corrigendum:

In the original article, we have noticed that the affiliation is listed wrongly for Filomena $\mathrm{Ng}$ as only 2 (Animal Science, Grasslands Research Centre, AgResearch Ltd., Palmerston North, New Zealand). The correct affiliation should be Filomena $\mathrm{Ng}^{1,2}$ (1-Institute of Fundamental Sciences, Massey University, Palmerston North, New Zealand; 2-Animal Science, Grasslands Research Centre, AgResearch Ltd, Palmerston North, New Zealand). The authors apologize for this oversight. This error does not change the scientific conclusions of the article in any way.

\section{AUTHOR CONTRIBUTIONS}

MC, WW, FN, JR, and DG approved the content of Corrigendum.

Conflict of Interest Statement: The authors declare that the research was conducted in the absence of any commercial or financial relationships that could be construed as a potential conflict of interest.

Copyright $\odot 2016$ Gagic, Ciric, Wen, Ng and Rakonjac. This is an open-access article distributed under the terms of the Creative Commons Attribution License (CC BY). The use, distribution or reproduction in other forums is permitted, provided the original author(s) or licensor are credited and that the original publication in this journal is cited, in accordance with accepted academic practice. No use, distribution or reproduction is permitted which does not comply with these terms. 